\title{
Application of chemical compounds during pre- harvesting to control post-harvesting green mold in citrus
}

\section{Aplicação de compostos químicos na pré-colheita para o controle do bolor verde em pós-colheita de citrus}

Marines Batalha Moreno Kirinus ${ }^{1 *}$; Keilor da Rosa Dorneles²; Pricila Santos Silva3; Caroline Farias Barreto ${ }^{1}$; Roberto Pedroso Oliveira4; Marcelo Barbosa Malgarim ${ }^{5}$

\section{Highlights}

Pre-harvest application of products for Penicillium digitatum control was promising.

ASM, MeJa, sodium selenite, potassium silicate, IMI, and TMT were evaluated.

Potassium silicate and sodium selenite decreased disease severity and expansion rate.

\begin{abstract}
This study aimed to evaluate the effect of system-acquired resistance inducing compounds applied during the pre-harvest of 'Navelina' orange and 'Ortanique' tangor in controlling post-harvest disease caused by Penicillium digitatum. The products applied were acibenzolar-s-methyl (ASM), imidacloprid (IMI), methyl jasmonate (MeJa), sodium selenite, potassium silicate, and thiamethoxam (TMT). Sterile distilled water was used as the control. The applications were administered 45, 30, and 15 days before harvesting. In 2015 and 2016, 840 fruits were randomly collected, and when they reached commercial maturation, they were sanitized, half were pierced with a needle in the equatorial region. The fruits were inoculated with a 10 $\mu \mathrm{L}$ spore suspension $\left(1 \times 10^{6}\right.$ conidia $\left.\mathrm{mL}^{-1}\right)$ of $P$. digitatum, in the equatorial region. The experiment was performed with three replicates, each comprising 10 fruits and repeated over two consecutive crop seasons. Disease incidence was evaluated on pierced (at 72 and $144 \mathrm{~h}$ after inoculation [hai]) and unperforated (at 360 hai) fruits. For pierced fruits, lesion expansion rate $\left(r_{L}\right)$, disease severity, expansion rate of sporulating area $\left(r_{E}\right)$, and sporulating area were evaluated. The area under the disease progress curve (AUDPC) and the area under the sporulating area progress curve were calculated. Both cultivars were susceptible; however,

1 Dras in Agronomic at Universidade Federal de Pelotas, UFPel, Pelotas, RS, Brazil. E-mail: marinesfaem@gmail.com; carol_fariasb@hotmail.com

2 Dr. in Phytopathology, UFPel, Pelotas, RS, Brazil. E-mail: keilor.rd@hotmail.com

3 Dra. in Vegetable Production at Universidade do Estado de Sannta Catarina, UDESC, Lages, SC, Brazil. E-mail: pricilassilva@hotmail.com

${ }^{4}$ Researcher at Empresa Brasileira de Pesquisa Agropecuária, EMBRAPA, Temperate Climate, Pelotas, RS, Brazil. E-mail: roberto.pedroso@embrapa.br

5 Prof. Dr. Course in Agronomy, UFPel, Pelotas, RS, Brazil. E-mail: malgarim@ufpel.edu.br

* Author for correspondence
\end{abstract}

Received: May 25, 2020 - Approved: May 07, 2021 
the $r_{L}$ and $r_{E}$ had lower values for 'Ortanique'. The tested products reduced the disease incidence in both cultivars. Potassium silicate reduced $r_{L}$ and $r_{E^{\prime}}$ whereas sodium selenite reduced $r_{E^{\prime}}$. The disease severity was reduced by potassium silicate, sodium selenite, and ASM. AUDPC was reduced by sodium selenite and potassium silicate treatments. Among the tested products, potassium silicate and sodium selenite applied during the pre-harvest of 'Navelina' orange and 'Ortanique' tangor had the highest reductions for disease incidence (ranging from $14 \%$ to $37 \%$, respectively) and severity $\left(60 \%\right.$ and $70 \%$, respectively), $r_{E}(50 \%$ for both compounds), and total sporulating area (55\% and $56 \%$, respectively), reducing the green mold in postharvested fruits caused by $P$. digitatum.

Key words: Alternative control. Citrus sinensis. Citrus reticulata. Penicillium digitatum. System-acquired resistance.

\section{Resumo}

Este estudo teve como objetivo avaliar os efeitos de compostos indutores dos sistemas de defesa adquirida aplicados na pré-colheita de laranja 'Navelina' e tangor 'Ortanique' para o controle de doença pós-colheita causada por Penicillium digitatum. Os produtos aplicados foram: acibenzolar-s-metil (ASM), imidaclopride (IMI), jasmonato de metila (MeJa), selenito de sódio (Se), silicato de potássio (Si), tiametoxam (TMT) e água estéril destilada foi utilizada como controle. Os produtos foram aplicados nas plantas em 45, 30 e 15 dias antes da colheita. Em 2015 e 2016, 840 frutos foram coletados aleatoriamente quando atingiram a maturação comercial e posteriormente foram higienizados, a metade deles foi perfurada com uma agulha na região equatorial. Os frutos foram inoculados com uma suspensão de $10 \mu \mathrm{L}\left(1 \times 10^{6}\right.$ conidia $\mathrm{mL}^{-1}$ ) de esporos de $P$. digitatum na região equatorial. $O$ experimento foi conduzido com três repetições, cada uma composta por 10 frutos, e repetida em duas safras consecutivas. A incidência da doença foi avaliada em frutos com (72 e 144 horas após a inoculação (hai)) e sem perfuração (com 360 hai). Para frutos perfurados, foram avaliadas a taxa de expansão da lesão $\left(r_{L}\right)$, a gravidade da doença, a taxa de expansão da área esporulante $\left(r_{E}\right)$ e a área esporulante. A área sob a curva de progresso da doença (AUDPC) e a área sob a curva de progresso da área esporulada foram determinadas. Ambas as cultivares foram suscetíveis, mas $r_{L}$ e $r_{E}$ apresentaram valores mais baixos em 'Ortanique'. Os compostos testados reduziram a incidência da doença em ambas as cultivares. O silicato de potássio reduziu $r_{L}$ e $r_{E^{\prime}}$ enquanto selenito de sódio reduziu $r_{E}$. A severidade da doença foi reduzida por silicato de potássio, selenito de sódio e ASM. O AUDPC foi reduzido pelos tratamentos com silicato de potássio, selenito de sódio. Dentre os produtos testados, silicato de potássio, selenito de sódio aplicados na pré-colheita de laranja 'Navelina' e tangor 'Ortanique', foram os que apresentaram maiores reduções na incidência das doenças (variando entre 14\% e 37\%, respectivamente), severidade da doença ( $60 \%$ e $70 \%$, respectivamente), $r_{E}$ (ambos a $0,50 \%$ ) e área total de esporulação (55\% e 56\%, respectivamente), reduzindo o bolor verde na pós-colheita de frutos, causado por P. digitatum.

Palavras-chave: Citrus sinensis. Citrus reticulata. Controle alternativo. Penicillium digitatum. Sistemas de defesa adquirida 


\section{Introduction}

Citrus fruits comprise the largest fruit production worldwide (Costa, Bazioli, Pontes, \& Fill, 2019), with a total worldwide production of approximately 103 million tons, including oranges, tangerines, lemons, and grapefruit, highlighting its economic importance (United States Department of Agriculture, 2021).

Approximately $34 \%$ of the global orange production occurs in Brazil (United States Department of Agriculture, 2021). In southern Brazil, an increase in the area cultivated with citrus has recently occurred, especially sweet orange 'Navelina' (Citrus sinensis (L.) Osbeck) and the hybrid tangor 'Ortanique' (C. sinensis (L.) Osbeck $\times$ C. reticulata Blanco) (Morton, 1987), which are consumed as table fruits.

Post-harvest decay caused by fungal pathogens is one of the major causes of fruit wastage being responsible for approximately $50 \%$ of the wastage in citrus fruits (Ladaniya, 2010). The main post-harvest pathogen of citrus fruits is the fungus Penicillium digitatum Sacc., which is the causal agent of green mold and can affect the fruits from the initial formation phase to its consumption after maturation (Sánchez-Torres \& Tuset, 2011). In arid zones and tropical subclimates, $P$. digitatum contributes to $90 \%$ of the total postharvest losses in citriculture (Macarisin et al., 2007). P. digitatum infection occurs through wounds on the surface of the fruit, which is favored under hot weather conditions (Palou, 2014).

The damage caused by $P$. digitatum generates huge economic losses because the infected fruits have a reduced storage period due to the synthesis of ethylene, a hormone that accelerates fruit maturation, reducing the shelf life (Laranjeira, Amorim, Bergamin, \& Aguilar-Vildoso, 2002). In addition, $P$. digitatum produces several toxins in infected fruits, such as patulin, which may contaminate fruit juices (Fischer, Palharini, Spósito, \& Amorim, 2013).

For the control of this pathogen, fungicides of benzimidazoles, thiabendazole, and imidazole groups are mainly used during pre- and post-harvest. However, isolates of Penicillium spp. resistant to fungicides have been reported (Fischer et al., 2013; SánchezTorres \& Tuset, 2011). The concern of consumers regarding food and environmental security have instigated the agricultural sector to seek alternative methods that can be used for disease control, minimizing the use of fungicides, (Ballester, Lafuente, Vos, Bovy, \& Gonzáles-Candelas, 2013) mainly during the final production stages, and reducing the possibility of fungicide residues on the fruits that may cause contamination to consumers.

An alternative is the use of commercial products permitted for citrus, but applied in low concentrations directly to the plant roots, unlike the usual spraying and its habitual risks, which have been reported in studies by Graham and Myers (2011) and Bagio, Canteri, Barreto and Leite (2016). These studies have included the use of neocotinoids, such as imidacloprid (IMI) and thiamethoxam (TMT), which showed positive effects in activating acquired resistance systems in plants.

The induction of plant defenses has been studied for post-harvest rot in citrus. This phenomenon is a natural defense mechanism, induced by biotic or abiotic agents, which involves a wide variety of metabolic and physiological responses against phytopathogenic microorganisms (Fallanaj et al., 2016). 
Several substances have shown the induction of resistance in plants against pathogens and can be used to manage green mold in citrus, including sodium selenite, silicon-based products, acibenzolar-smethyl (ASM), methyl jasmonate (MeJa), and neonicotinoids, such as TMT and IMI.

Sodium selenite presents a high antioxidant capacity that regulates the gene expression involved in ethylene biosynthesis (Zhu, Chen, Shi, \& Zhang, 2017), improving the induction of plant defense systems (Hasanuzzaman, Nahar, \& Fujita, 2014). Potassium silicate operates in the metabolic system of plants, inducing resistance (Imtiaz et al., 2016), which is responsible for multiple roles in cell growth and development, combining physical and chemical barriers such as increasing cell wall fragments (Zhichao et al., 2016), enzymatic activity of plant tissues (Conceição, Felix, Mariano, Medeiros, \& Souza, 2014), and increasing plant defenses against pathogens by altering defense gene expression, enzyme activities, cell wall lignification, and other defenses (Debona, Rodrigues, \& Datnoff, 2017; Rodrigues, Resende, Dallagnol, \& Datnoff, 2015). ASM, a functional analog of salicylic acid that can activate plant defenses, such as pathogenesis-related proteins, has been used in citrus against $P$. digitatum, $P$. italicum, and Xanthomonas citri subsp. citri (Graham \& Myers, 2011; Rocha, Maraschin, \& DiPiero, 2015). MeJa is the methyl ester of jasmonic acid. During molecular signaling, MeJa is involved in the induction of defense genes in citrus against $P$. digitatum and $P$. italicum (Moosa, Sahi, Khan, \& Malik, 2019). In loquats fruits, promising results in systemic resistance induction, interfering in the physiological and biochemical responses, were achieved with
MeJA treatment (Cai, Cao, Yang, \& Zheng, 2011; Cao, Yang, Cai, \& Zheng, 2014). Neocotinoid substances such as IMI and TMT have been used to induce systemic acquired resistance in citrus plants successfully (Bagio et al., 2016; Graham \& Myers, 2011).

The defense responses induced by these products include enzymes of the antioxidant defense system, pathogenesisrelated proteins, biosynthesis of phenylpropanoid compounds, and increasing the activities of enzymes with direct action against pathogens (Graham \& Myers, 2016; Hua et al., 2017; Rocha Neto, Maraschi, \& Di Piero, 2015; Qing-Yan et al., 2016; Quaglia, Ederli, Pasqualini, \& Zazzerini, 2011; Rodrigues et al., 2015; Zhu et al., 2017) delaying the development of the disease symptoms (Amelio, Marzachi, \& Bosco, 2010). Therefore, induction of defenses emerges as a promising alternative for the control of green mold in citrus.

In the present study, the effect of compounds with defense-inducing potential applied during the pre-harvest of 'Navelina' orange and 'Ortanique' tangor to induce postharvest resistance against $P$. digitatum was evaluated.

\section{Materials and Methods}

\section{Plant material and pest management}

The experiment was performed on plants from two commercial citrus orchards during the 2015 and 2016 crop seasons, both located in the city of Pelotas, Rio Grande do Sul, Brazil. The orange 'Navelina' (C. sinensis L. Osbeck) orchard is located in Santa Silvana district $\left(31^{\circ} 25^{\prime} 58^{\prime \prime} \mathrm{S}, 52^{\circ} 16^{\prime} 58^{\prime \prime} \mathrm{W}\right.$ and $193 \mathrm{~m}$ 
altitude). The 'Ortanique' tangor (C. sinensis L. Osbeck $\times$ C. reticulata Blanco) orchard is

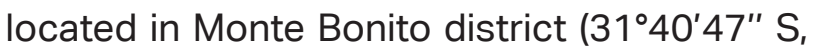
$52^{\circ} 26^{\prime} 24^{\prime \prime} \mathrm{W}$ and $60 \mathrm{~m}$ altitude). The climate of the region is of the Cfa type, temperate or subtropical humid with hot summers (Köppen \& Geiger, 1928), and an average annual precipitation of $1590 \mathrm{~mm}$, average annual temperature of $18.4{ }^{\circ} \mathrm{C}$ and average annual relative humidity of $78.8 \%$ (Instituto Nacional de Meteorologia [INMET], 2019).

Chemical pest management, when required, was performed based on the phenological developmental stage (scale adapted from Barbasso, Pedro and Pio (2005) or based on the pest occurrence). Fungicide (Trifloxystrobin and tebuconazol [60 + $120 \mathrm{~g}$ a.i. ha $^{-1}$; Nativo ${ }^{\circledR}$, Bayer]) was applied to plants with newly formed fruits (stage 6) (first application), followed by a second application with a 30-day interval. A Bordeaux mixture, prepared with 10 $\mathrm{g} \mathrm{L}^{-1}$ copper sulfate and $10 \mathrm{~g} \mathrm{~L}^{-1}$ pure lime, was applied from flowering stage 1 and repeated every 45 days, totaling five applications for each season. The last application of Bordeaux mixture occurred 60 days before fruit harvest. The insecticides applied were dimethoate (150 mL $100^{-1} \mathrm{~L}_{\text {of }}$ water; Dimexion ${ }^{\circledR}$, Nortox) and abamectin $\left(30 \mathrm{~mL} 100^{-1}\right.$ liters of water; Kraft $36^{\circledR}$, Nortox). Dimethoate was applied three times, and spraying was performed when infestations of leafminer (Phyllocnistis citrella) and sparrowfish (Selenaspidus articulatus) were detected. Abamectin was used to combat fake rust mite (Phyllocoptruta oleivora), white mite (Polyphagotarsonemus latus), and leafminer, and three applications were performed during the production cycle.

\section{Products and their application on plants}

The seven treatments (control and six products - described below) were arranged in completely randomized blocks, with five replicates and each constituted three plants. The central plant of each replicate was used for fruit sampling.

The products applied were ASM (100 $\mathrm{mg} \mathrm{L}^{-1}$ ) (Bion ${ }^{\circledR}$, Syngenta), which contained 50\% ASM; MeJa (10 mg L-1) (Sigma-Aldrich), which contained 95\% MeJa and was diluted with $1 \%$ acetone; TMT (2000 $\mathrm{mg} \mathrm{L}^{-1}$ ) (Actara ${ }^{\circledR}$, Syngenta), which contained 25\% TMT; IMI (714 $\mathrm{mg} \mathrm{L}^{-1}$ ) (Evidence ${ }^{\circledR}$, Bayer), which contained $70 \%$ IMl; anhydrous sodium selenite (Synth), which contained $95 \% \mathrm{Se}$, as selenium $(10 \mathrm{mg}$ $\mathrm{L}^{-1}$ ) source; and potassium silicate (Fertisilício ${ }^{\circledR}$, Plant Defender), which contained $12.5 \% \mathrm{Si}$, as silicon (400 $\mathrm{mg} \mathrm{L}^{-1}$ ) source. The plants sprayed with sterile distilled water served as the control.

The product sprays on the plants in the orchards were undertaken 45, 30, and 15 days before harvesting. The potassium silicate, ASM, and MeJa products were sprayed using a backpack sprayer (Model 10L, Guarani), with a fan-type nozzle (XR 110.02) and fine droplet size (101-200 $\mu$ ), throughout the canopy of the plant, at a volume of $2 \mathrm{~L}$ per plant. Sodium selenite, TMT, and IMI were applied in the soil, at a volume of $2 \mathrm{~L}$ per plant, around the trunk, $50 \mathrm{~cm}$ from it. In all sprayed treatments, $0.1 \%$ Silwet $\mathrm{L}-77^{\circledR}$ nonionic adhesive spreader was added to the mixture. 


\section{Fruit harvesting and storage}

The fruits were randomly collected from the plant crown in the four quadrants when they reached the ideal commercial maturation (stage 10, where 'Ortanique' soluble solids/titratable acidity (ratio) $\geq 6$ and 'Navelina' ratio $\geq 10$ ) (Barbasso et al., 2005). The fruits were then placed in clean, disinfected plastic boxes and transported to the Post-Harvest Fruit Physiology and Technology Laboratory, Department of Plant Science, Federal University of Pelotas. In the laboratory, the fruits were pre-selected by standardization with visual assessment and immediately exposed to a pre-cooling period for $24 \mathrm{~h}$ at $15^{\circ} \mathrm{C}$. Subsequently, the fruits were sanitized with sodium hypochlorite $(200 \mathrm{mg}$ $\left.\mathrm{L}^{-1}\right)$ for $10 \mathrm{~min}$ at room temperature $\left(18-23^{\circ} \mathrm{C}\right)$, followed by washing twice with sterile distilled water and dried by forced ventilation. In total, 1680 fruits were evaluated. The fruits were placed in plastic trays of $8.0 \times 31.0 \times 50.0 \mathrm{~cm}$ (height $\times$ width $\times$ length).

\section{Fungus cultivation and inoculation}

The fungal isolate of $P$. digitatum (LIPPPd01/2016) used in the present study was obtained from symptomatic orange fruits collected in a commercial orchard in Pelotas/ RS. The identity of the isolate was confirmed by morphological analysis of conidia and conidiophores, and molecular analysis with amplification of the ITS region using the ITS1-KYO2 and ITS4 primer pair (Toju, Tanabe, Yamamoto, \& Sato, 2012), resulting in a single fragment with a size of 621 base pairs deposited in GenBank (No. KY558584).
The fungus was preserved following the Castellani method. For inoculum production, the fungus was growth on potato-dextroseagar medium (Fluka, Sigma, USA) at $25 \pm 1^{\circ} \mathrm{C}$ and a photoperiod of $12 \mathrm{~h}$. Colonies at seven days old were used to prepare the conidial suspension $\left(1 \times 106\right.$ conidia $\left.\mathrm{mL}^{-1}\right)$ using sterile distilled water.

The inoculation was performed on unperforated and pierced fruits. For pierced fruits, the wound was administered in the equatorial region $(0.5 \mathrm{~mm}$ diameter and $2-3$ $\mathrm{mm}$ depth) before inoculation, using a sterile needle. An aliquot of $10 \mu \mathrm{L}$ of $P$. digitatum spore suspension was transferred to the equatorial region of each fruit (on the wound for pierced fruits) using a micropipette (Labmate Brand, Model HTL). After inoculation, the fruits were stored over moist paper, but without direct contact, inside plastic trays $(9.8 \times 40.7 \times 60.8$ $\mathrm{cm})$ covered with transparent polyethylene bags (thickness of $0.30 \mathrm{~mm}$ ) and maintained at $24 \pm 1^{\circ} \mathrm{C}$, relative humidity of $90 \pm 5 \%$, and photoperiod of $12 \mathrm{~h}$.

\section{Experimental design in the laboratory}

A $2 \times 7$ factorial design consisting of the treatments applied on the plants in the field (six products and control) and the citrus cultivars ('Navelina' orange and 'Ortanique' tangor) in two fungal isolate inoculation (pierced fruits and unperforated fruits) were arranged in a completely randomized design with three replicates, each containing 10 fruits. The experiment was performed twice (2015 and 2016), with a total of 1680 analyzed fruits. 


\section{Disease evaluation}

The variables evaluated were green mold incidence, rate of lesion expansion $\left(r_{L}\right)$, disease severity, expansion rate of sporulating area $\left(r_{E}\right)$, and sporulating area.

Disease evaluations on the perforated fruits were performed at 72 and 144 hours after inoculation (hai). The disease incidence was evaluated daily by quantifying fruits with anasarca symptoms on the inoculation site and expressed as a percentage. The $r$ indicates the speed of host tissue colonization by the pathogen and was calculated from the daily lesion measurements up to 144 hai using a digital electronic caliper (stainless steel, hardened, China). The $r_{E}$ indicates the speed of expansion of the area with visible sporulation of $P$. digitatum and was obtained similar to $r_{L}$, but considered only the area with fungal spores. The disease severity was quantified daily and expressed as the percentage of the total area of fruit affected by anasarca. The sporulating area was measured daily as performed for disease severity, but considering only the area with the presence of spores. The disease severity and sporulating area values were calculated by the area under the disease progress curve (AUDPC) and the area under the sporulating area progress curve (AUSPC), respectively, using the formulas proposed by Shaner and Finney (1977).

For unperforated fruits, the incidence of green mold was evaluated only at 360 hai, due to the longer incubation period of the disease.

\section{Statistical analysis}

Data were analyzed for normality using the Shapiro-Wilk test and for homoscedasticity using the Hartley test. Data were then submitted to analysis of variance ( $p \leq 0.05)$. In the case of significance, the effect of products was analyzed by Tukey's test $(p \leq 0.05)$ and the cultivars by t-test ( $p \leq 0.05)$.

\section{Results and Discussion}

A significant interaction between the factors of cultivar and products was only observed for the disease incidence.

In pierced fruits, all products significantly decreased the green mold incidence, regardless of cultivar (Table 1). The greatest reduction in the disease incidence was achieved with potassium silicate, regardless of the cultivar, followed by sodium selenite and ASM for cultivar Navelina, at 72 hai and sodium selenite and MeJa at 144 hai. For Ortanique, sodium selenite and IMI decreased the disease incidence more efficiently at 72 hai, whereas ASM and sodium selenite were more efficient at 144 hai (Table 1). 
Table 1

Incidence of green mold on fruits of 'Navelina' orange and 'Ortanique' tangor inoculated with Penicillium digitatum through piercing wounds or on unperforated surface treated during pre-harvesting with different products

\begin{tabular}{|c|c|c|c|c|c|c|}
\hline \multirow{3}{*}{ Products } & \multicolumn{4}{|c|}{ Pierced fruits } & \multirow{2}{*}{\multicolumn{2}{|c|}{$\begin{array}{c}\text { Unperforated fruits } \\
360 \text { hai* }^{*}\end{array}$}} \\
\hline & \multicolumn{2}{|c|}{72 hai* } & \multicolumn{2}{|c|}{144 hai* $^{*}$} & & \\
\hline & Navelina & Ortanique & Navelina & Ortanique & Navelina & Ortanique \\
\hline ASM & $37.5 \mathrm{~dB}$ & $50.0 \mathrm{bA}$ & $95.9 \mathrm{bA}$ & $83.2 \mathrm{~dB}$ & $10.7 \mathrm{cA}$ & $5.6 \mathrm{cB}$ \\
\hline IMI & $45.8 \mathrm{bA}$ & $29.1 \mathrm{fB}$ & $95.8 \mathrm{bA}$ & $95.8 \mathrm{bA}$ & $0.0 \mathrm{fB}$ & $8.3 \mathrm{bA}$ \\
\hline MeJa & $41.6 \mathrm{cB}$ & $45.8 \mathrm{cA}$ & $87.5 \mathrm{cB}$ & $91.5 \mathrm{cA}$ & $3.6 \mathrm{eB}$ & $5.5 \mathrm{cA}$ \\
\hline $\mathrm{Se}$ & $16.6 \mathrm{fB}$ & $41.6 \mathrm{dA}$ & $87.4 \mathrm{cA}$ & $83.3 \mathrm{~dB}$ & $10.7 \mathrm{cA}$ & $5.6 \mathrm{cB}$ \\
\hline $\mathrm{Si}$ & $16.7 \mathrm{fB}$ & $20.8 \mathrm{gA}$ & $62.5 \mathrm{~dB}$ & $70.7 \mathrm{eA}$ & $7.1 \mathrm{dA}$ & $2.8 \mathrm{~dB}$ \\
\hline TMT & $33.3 \mathrm{eB}$ & $37.5 \mathrm{eA}$ & $95.9 \mathrm{bA}$ & $91.6 \mathrm{cB}$ & $14.3 \mathrm{bA}$ & $2.8 \mathrm{~dB}$ \\
\hline Control & 66.6 aA & $62.5 \mathrm{aB}$ & $100.0 \mathrm{aA}$ & $100.0 \mathrm{aA}$ & $39.3 \mathrm{aA}$ & $25.2 \mathrm{aB}$ \\
\hline CV (\%) & 5.4 & 4.8 & 2.2 & 2.2 & 15.2 & 25.0 \\
\hline
\end{tabular}

Products: acibenzolar-s-methyl (ASM, $\left.100 \mathrm{mg} \mathrm{L}^{-1}\right)$, imidacloprid (IMI, $\left.714 \mathrm{mg} \mathrm{L}^{-1}\right)$, methyl jasmonate (MeJa, $\left.10 \mathrm{mg} \mathrm{L} \mathrm{L}^{-1}\right)$, sodium selenite (Se, $10 \mathrm{mg} \mathrm{L}^{-1}$ ), potassium silicate (Si, $400 \mathrm{mg} \mathrm{L}^{-1}$ ), thiamethoxam (TMT, $2000 \mathrm{mg} \mathrm{L}^{-1}$ ) and control (sterile distilled water). $\mathrm{CV}=$ coefficient of variation. Values followed by the same lowercase letter in the column do not differ by Tukey's test $(p \leq 0.05)$ comparing the inducers in each cultivar for each evaluated period. Means accompanied by the same uppercase letter in the row do not differ from each other by $t$-test $(p \leq 0.05)$ comparing the cultivars in each inducer, for each evaluated period. *Hours after inoculation.

For the control treatment, no significant variation for disease incidence occurred between the cultivars (Table 1). However, the fruits of the cultivar Navelina treated with potassium silicate and MeJa showed lower disease incidence than the fruits of the cultivar Ortanique (Table 1). In contrast, fruits of the cultivar Ortanique treated with IMI and ASM showed lower disease incidence than the fruits of the cultivar Navelina for the same treatments, especially after 72 and 144 hai, respectively (Table 1$)$.

In unperforated fruits, the green mold incidence was significantly higher in the cultivar Navelina than in the cultivar Ortanique (Table 1). All products decreased the disease incidence by more than $70 \%$, except for TMT in the cultivar Navelina and IMI in the cultivar Ortanique (Table 1) compared to control. MeJa and the neocotinoids showed a great reduction in incidence of $P$. digitatum. Navelina had the highest percentage of disease incidence for all treatments, expect for IMI and MeJa. This behavior possibly occurred because of the modification extent of the polysaccharides in the cell wall and the expression and regulation of the cell wall-modifying enzymes (Goulao \& Oliveira, 2008).

Comparing cultivars for lesion size and sporulation area, differences were observed for the $r_{L}$ and $r_{E}$ that were lower in the cultivar Ortanique (Figure $1 \mathrm{~A}$ and $\mathrm{E}$ ).

Only the potassium silicate produced lower $r_{L}$ and $r_{E^{\prime}}$ than the control, conferring lower disease severity and sporulating area (Figure 1B and F). Compared to the control, sodium selenite and ASM significantly reduced the disease severity. 
The sporulating area did not differ significantly among cultivars for the different treatments; except for TMT, all products reduced the sporulating area (Figure $2 \mathrm{~A}$ and $B)$. The AUDPC was significantly lower in the cultivar Ortanique than in the cultivar Navelina (Figure 2C). The highest reduction, 39.5\%, in AUDPC was obtained with the potassium silicate treatment followed by sodium selenite compared to the control treatment (Figure 2D). Cultivars did not influence the AUSPC, which was significantly lower in all treatments, when compared to control treatment (Figure $2 \mathrm{E}$ and $\mathrm{F}$ ).
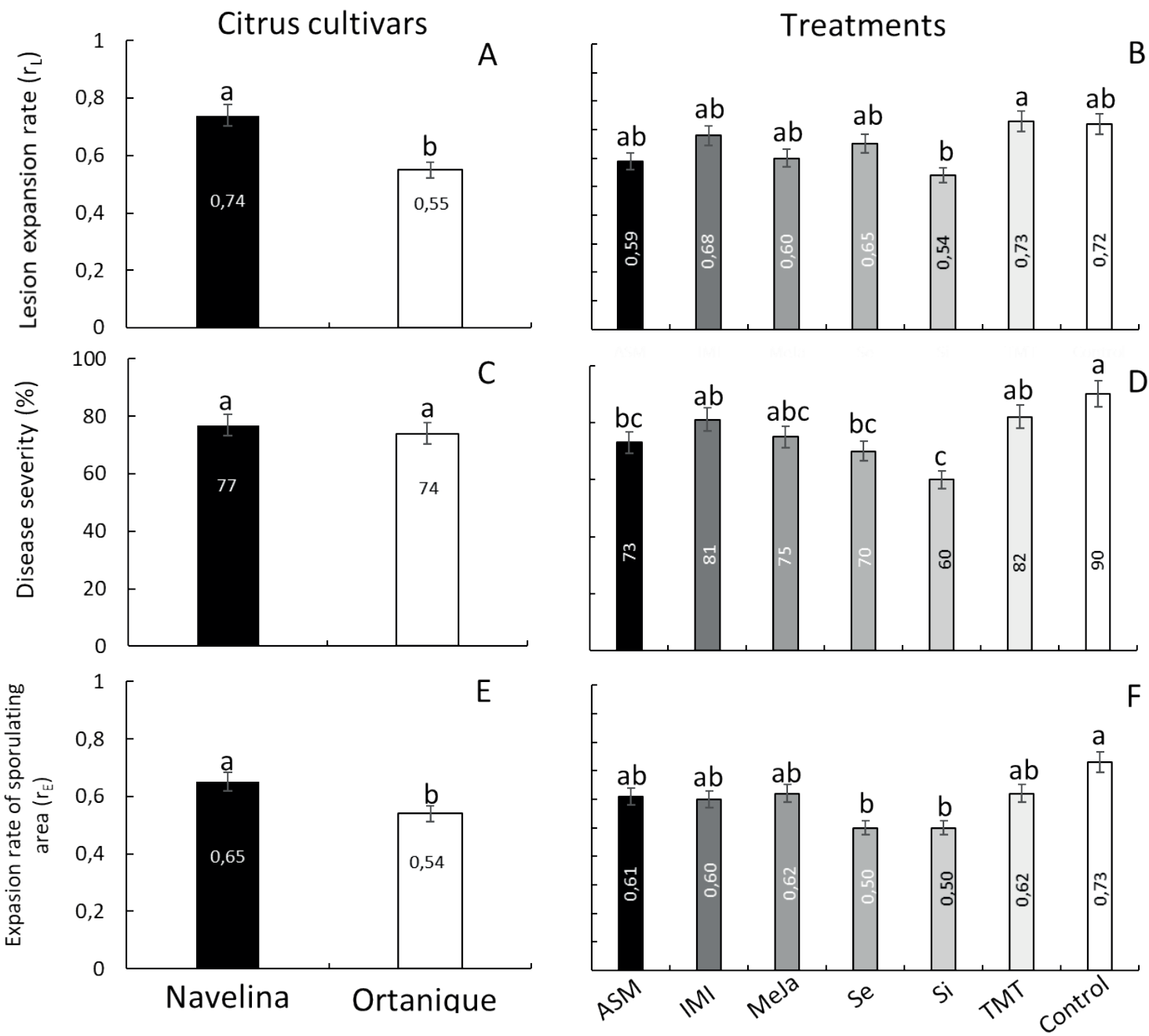

Figure 1. Lesion expansion rate $\left(r_{L}\right)(A-B)$, green mold severity (anasarca area \%) (C-D) and expansion rate of sporulating area $\left(r_{E}\right)(E-F)$ in 'Navelina' orange and 'Ortanique' tangor fruits, treated in pre-harvest with: acibenzolar-s-methyl (ASM, $100 \mathrm{mg} \mathrm{L}^{-1}$ ), imidacloprid (IMI, $714 \mathrm{mg}$ $\left.\mathrm{L}^{-1}\right)$, methyl jasmonate (MeJa, $\left.10 \mathrm{mg} \mathrm{L}^{-1}\right)$, sodium selenite (Se, $10 \mathrm{mg} \mathrm{L}^{-1}$ ), potassium silicate (Si, $400 \mathrm{mg} \mathrm{L}^{-1}$ ), thiamethoxam (TMT, $2000 \mathrm{mg} \mathrm{L}^{-1}$ ) and control (sterile distilled water), and inoculated with Penicillium digitatum. Means followed by the same letter do not differ by t-test $(p \leq 0.05)$ comparing the citrus cultivars. Means followed by the same letter do not differ by Tukey's test ( $p \leq$ 0.05) comparing the inducers. Bars indicate standard deviation. 


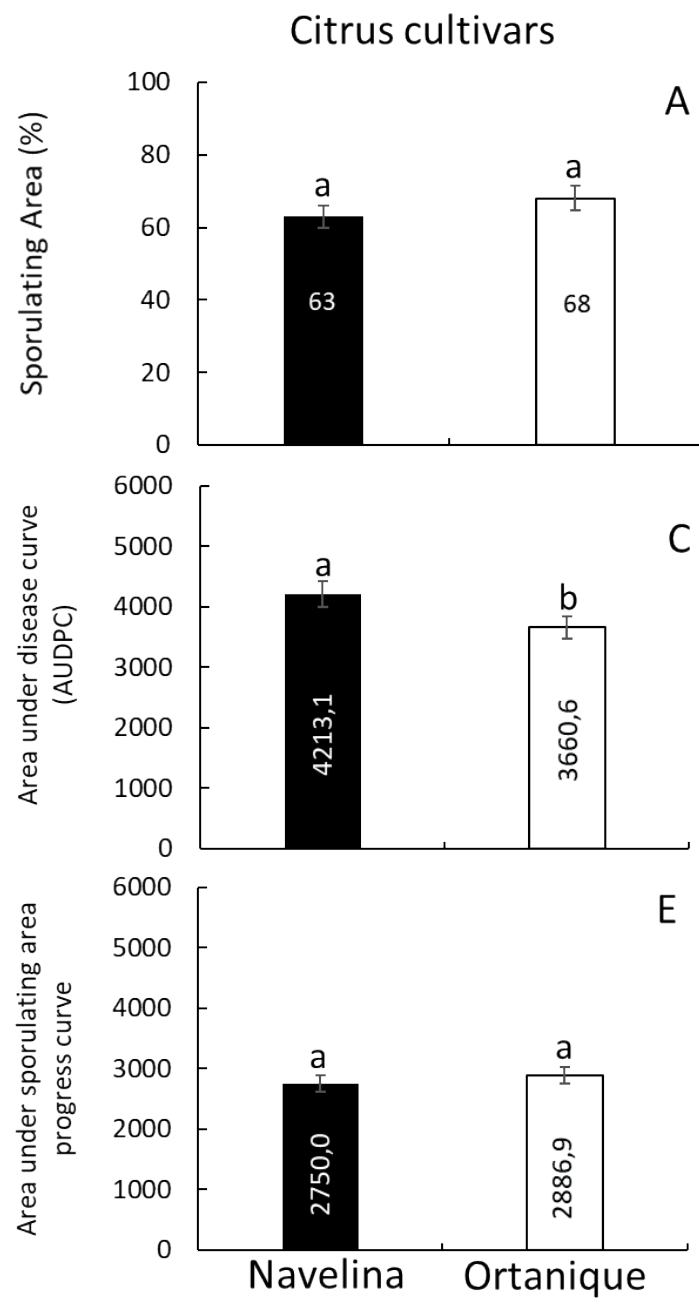

Treatments
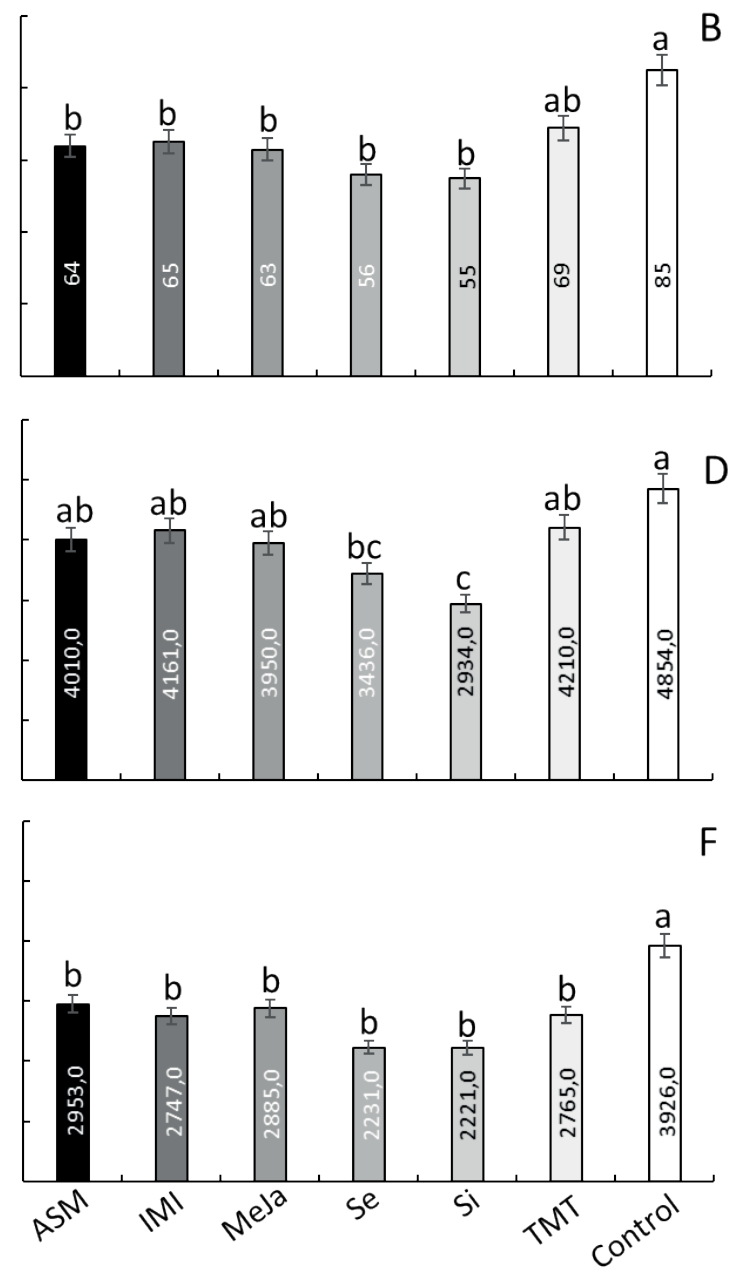

Figure 2. Sporulating area (area with visible pathogen structures\%) (A-B), area under disease progress curve (AUDPC) (C-D) and area under sporulating area progress curve (AUSPC) (E-F) in 'Navelina' orange and 'Ortanique' tangor fruits, treated in pre-harvest with: acibenzolar-s-methyl (ASM, $100 \mathrm{mg} \mathrm{L}^{-1}$ ), imidacloprid (IMI, $714 \mathrm{mg} \mathrm{L}^{-1}$ ), methyl jasmonate (MeJa, $10 \mathrm{mg} \mathrm{L}^{-1}$ ), sodium selenite (Se, $\left.10 \mathrm{mg} \mathrm{L}^{-1}\right)$, potassium silicate $\left(\mathrm{Si}, 400 \mathrm{mg} \mathrm{L}^{-1}\right)$, thiamethoxam (TMT, $2000 \mathrm{mg} \mathrm{L}^{-1}$ ) and control (sterile distilled water), and inoculated with Penicillium digitatum. Means followed by the same letter do not differ by t-test $(p \leq 0.05)$ comparing the citrus cultivars. Means followed by the same letter do not differ by Tukey's test $(p \leq 0.05)$ comparing the inducers. Bars indicate standard deviation.

Many alternatives that induce systemic acquired resistance or improve resistance systems in plants have been widely studied as alternatives for the control of diseases, especially for those species that do not have effective control measures and have a high potential for economic damage (Vallad \& Goodman, 2004). The results in the present study demonstrate that pre-harvesting treatment with products that induce resistance decreased the severity of green mold caused by $P$. digitatum during post-harvest for both 
citrus cultivars, the 'Navelina' orange and 'Ortanique' tangor. Among the tested products, potassium silicate and sodium selenite had the greatest reductions in disease severity, regardless of the citrus genotype.

$P$. digitatum infection occurs mainly via its infection hyphae penetration into wounds present in the fruit epidermis, which release exudates and stimulate germination of the conidia deposited on the surface of the fruit (Fischer et al., 2013). In the present study, a higher incidence and expression of green mold symptoms were observed earlier (at 72 hai) in pierced fruits, whereas unperforated fruits showed a low disease incidence, even at 360 hai.

For the different products, the preharvesting treatment of plants reduced the incidence of post-harvest green mold and showed a reduction in the $r_{L}$ and AUDPC. The adverse effect on colonization of the pathogen caused by the application of resistance inducers was observed by decreasing the $r_{L}$. This variable refers to the colonization rate of the pathogen in the host tissue, directly influencing the final disease severity (Menegon, Forcelini, \& Fernandes, 2005). The AUDPC summarizes the epidemic as a whole, and considers the stress that the crop underwent within a certain time scale (Campbell \& Madden, 1990).

The lower $r_{E}$ is characterized by the growth of white mycelium on the affected tissue and is sequentially coated by a dense mass of conidia (Fischer et al., 2013), and affects the onset speed of the secondary infection cycle. As observed, the application of all treatments reduced the expansion rate and area of sporulation, with potassium silicate and sodium selenite standing out among all treatments. For the other treatments, despite reducing the $r_{E}$ they did not differ significantly from the control. ASM, IMI, MeJa, sodium selenite, and potassium silicate were efficient in decreasing the total sporulating area of the fruits. The delay in the appearance of the reproductive structures of the pathogen contributes to the reduction of the source of secondary inoculum because the large number of conidia present on the surface of the fruits is easily dispersed through the air, leading to a high incidence of the disease in the orchard and packing house, and spreading to the storage places and supermarket shelves (Fischer et al., 2013).

In the present study, the effect on the disease caused by $P$. digitatum was not associated with the genotypic effect because both cultivars were susceptible to the pathogen. Rather, the effect was associated with the compounds commonly known as resistance inducers applied during the preharvesting step. These compounds, acting on the primary and secondary metabolism of the plant, potentiate the structural and biochemical defense mechanisms, which restrict the processes of infection, colonization, and reproduction of the pathogen (Vallad \& Goodman, 2004).

Among the compounds tested, sodium selenite and potassium silicate showed the most promising results for the post-harvest control of $P$. digitatum. The action mode in the plant, inducing the post-harvest effect, was not investigated during the present study. For potassium silicate, the benefits of foliar application are attributed to the silicate polymerization above the leaf cuticle, providing a physic-chemical barrier against stressors (Reis, Arf, Silva, Sá, \& Buzetti, 2008; Rodrigues et al., 2015), with leaf application not 
causing significant changes in the biochemical responses of the plant against the pathogens studied (Dallagnol, Rodrigues, Pascholati, Fortunato, \& Camargo, 2015; Rodrigues et al., 2015). In the melon, leaf application of potassium silicate reduced the rate of colony expansion and conidia production per colony of powdery mildew (Podosphaera xanthii), a typical pathogen of external colonization of the host tissue (Dallagnol et al., 2015). However, $P$. digitatum in citrus penetrates through wounds originating from environmental factors, such as wind, hail, and insects, or during the harvest process, transport, and subsequent treatments (Perez et al., 2017). This fungus spreads on several skin oil glands through pores and wounds (Ghooshkhaneh, Golzarian, \& Mamarabadi, 2018). The reduction of $r_{L}$ might occur due to many factors, such as hydrogen peroxide production as a plant response, disturbances in catalase production secreted by fungus, maintenance of fruit $\mathrm{pH}$ reducing the efficiency of organic acid secretion by the pathogen (Costa et al., 2019), and phenolic compounds in citrus fruits (Kirinus et al., 2018). Reducing pre- and post-harvest losses is a constant challenge in the citrus production chain. The inclusion of resistance inducers in disease management is a promising alternative based on the present study results.

\section{Conclusion}

Among the tested products, potassium silicate and sodium selenite had the greatest reductions in disease severity, expansion rate of sporulating area, and total sporulating area in the fruits, regardless of the citrus genotype, and decreased the influence of green mold when applied during pre-harvest.

\section{References}

Amelio, R. D., Marzachi, C., \& Bosco, D. (2010). Activity of benzothiadiazole on chrysanthemum yellows phytoplasma ('Candidatus Phytoplasma asteris') infection in daisy plants. Journal Crop Protection 29(10), 1094-1099. doi: 10.10 16/j.cropro.2010.03.011

Bagio, T. Z., Canteri, M. G., Barreto, T. P., \& Leite, R. P., Jr. (2016). Activation of systemic acquired resistance in citrus to control huanglongbing disease. Semina: Ciências Agrárias, 37(4), 1757-1766. doi: 10.5433/1679-0359.2016v37n4p1757

Ballester, A. R., Lafuente, M. T., Vos, R. C. H., Bovy, A. G., \& Gonzáles-Candelas, L. (2013). Citrus phenylpropanoids and defence against pathogens. Part I: Metabolic profiling in elicited fruits. Food Chemistry, 136(1), 178-185. doi: 10.10 16/j.foodchem.2012.07.114

Barbasso, D. V., Pedro, M. J., Jr., \& Pio, R. M. (2005). Caracterização fenológica de variedades do tipo Murcott em três portaenxertos. Revista Brasileira Fruticultura, 27(3), 399-403. doi: 10.1590/S0100-2945 2005000300015

Cai, Y., Cao, S., Yang, Z., \& Zheng, Y. (2011). MeJA regulates enzymes involved in ascorbic acid and glutathione metabolism and improves chilling tolerance in loquat fruit. Postharvest Biology Technology, 59(3), 324-326. doi: 10.1016/j.postharvbio.2010. 08.020

Campbell, C. L., \& Madden, L. V. (1990). Introduction to plant disease epidemiology. New York: John Wiley. 
Cao, S., Yang, Z., Cai, Y., \& Zheng, Y. (2014). Antioxidant enzymes and fatty acid composition as related to disease resistance in postharvest loquat fruit. Food Chemistry, 163, 92-96. doi: 10.10 16/j.foodchem.2014.04.084

United States Department of Agriculture (2021). Citrus: World Markets and Trade. Washington, DC: Foreign Agricultural Service. Retrieved from https://apps.fas. usda.gov/psdonline/circulars/citrus.pdf

Conceição, C. S., Felix, K. C. S., Mariano, R. L. R., Medeiros, E. V., \& Souza, E. B. (2014). Combined effect of yeast and silicon on the control of bacterial fruit blotch in melon. Scientia Horticulturae, 174, 164170. doi: 10.1016/j.scienta.2014.05.027

Costa, J. H., Bazioli, J. M., Pontes, J. G. M., \& Fill, T. P. (2019). Penicillium digitatum infection mechanisms in citrus: What do we know so far? Fungal Biology, 123(2019), 584593. doi: 10.1016/j.funbio.2019.05.004

Dallagnol, L. J., Rodrigues, F. A., Pascholati, S. F., Fortunato, A. A., \& Camargo, L. E. A. (2015). Comparison of root and foliar applications of potassium silicate in potentiating post-infection defences of melon against powdery mildew. Plant Pathology, 64, 1085-1093. doi: 10.1111/ ppa.12346

Debona, D.., Rodrigues, F. A., \& Datnoff, L. E. (2017). Silicon's role in abiotic and biotic plant stresses. Annual Review of Phytopathology, 55, 85-107. doi: 10.1146/ annurev-phyto-080516-035312

Fallanaj, F., Ippolito, A., Ligorio, A., Garganese, F., Zavanell, A. C., \& Sanzani, S. M. (2016). Electrolyzed sodium bicarbonate inhibits Penicillium digitatum and induces defence responses against green mould in citrus fruit. Postharvest Biology and Technology, 115, 18-29. doi: 10.1016/j. postharvbio.2015.12.009

Fischer, I. H., Palharini, M. C. A., Spósito, M. B., \& Amorim, L. (2013). Postharvest diseases in 'Pera' Orange cultivates in organic and conventional systems and resistance of Penicillium digitatum to fungicides. Summa Phytopathologica, 39(1), 28-39. doi: 10.1590/S0100-54052 013000100005

Ghooshkhaneh, N. G., Golzarian, M. R., \& Mamarabadi, M. (2018). Detection and classification of citrus green mold caused by Penecillium digitatum using multispectral imaging. Journal of the Science of Food and Agriculture, 98(9), 3542-3550. doi: 10.1002/jsfa.8865

Goulao, L. F., \& Oliveira, C. M. (2008). Cell wall modifications during fruit ripening: when a fruit is not the fruit. Trends in Food Science \& Technology, 19(1), 4-25. doi: 10.1016/j.tifs.2007.07.002

Graham, J. H., \& Myers, M. E. (2011). Soil application of SAR inducers imidacloprid, thiamethoxam, and acibenzolar-Smethyl for citrus canker control in young grapefruit trees. Plant Disease, 95(6), 720729. doi: 10.1094/PDIS-09-10-0653

Graham, J. H., \& Myers, M. E. (2016). Evaluation of soil applied systemic acquired resistance inducers integrated with copper bactericide sprays for control of citrus canker on bearing grapefruit trees. Journal Crop Protection, 90, 157-162. doi: 10.1016/j.cropro.2016.09.002

Hasanuzzaman, M., Nahar, K., \& Fujita, M. (2014). Silicon and selenium: two vital 
trace elements that confer abiotic stress tolerance to plants. In P. Ahmad, \& S. Rasool, Emerging techonologies and management of crop stress tolerance (Chapter 16, pp. 377-422). New Delhi: Biological Techniques.

Hua, L., Jiangtao, S. Y. H., Chunqiang, L., Mijing, J., Zhengke, Z., \& Jingping, R. (2017). The effect of 1-methylcyclopropene, methyl jasmonate and methyl salicylate on lignin accumulation and gene expression in postharvest 'Xuxiang' kiwifruit during cold storage. Postharvest Biology and Technology, 124, 107-118. doi: 10.1016/j. postharvbio.2016.10.003

Imtiaz, M., Rizwan, M. S., Mushtaq, M. A., Ashraf, A., Shahzad, S. M., \& Yousaf, B. (2016). Silicon occurrence, uptake, transport and mechanisms of heavy metals, minerals and salinity enhanced tolerance in plants with future prospects: a review. Journal of Environmental Management, 183(3), 521529. doi: 10.1016/j.jenvman.2016.09.009

Instituto Nacional de Meteorologia (2019). Boletim Agroclimatológico Anual. Retrieved from http://www.inmet.gov.br/ portal/index.php?r=bdmep/bdmep

Kirinus, M. B. M., Barreto, C. F., Silva, P. S. Oliveira, R. P., Malgarim, M. B., \& Fachinello, J. C. (2018). 'Navelina' orange submitted to pre-harvest resistance inducers. Acta Scientiarum Agronomy, 40(1), e39465. doi: 10.4025/actasciagron.v40i1.39465

Köppen, W., \& Geiger, R. (1928). Klimate der erde. Gotha: Verlag Justus Perthes.

Ladaniya, M. S. (2010). Citrus fruit: biology, technology, and evaluation. Goa: Academic Press.
Laranjeira, F. F., Amorim, L., Bergamin, A., F'., \& Aguilar-Vildoso, C. I. (2002). Controle de doenças causadas por fungos e bactérias em citros. In L. Zambolim, F. X. Ribeiro do Vale, A. J. A. Monteiro, \& H. Costa (Eds.), Controle de doenças de plantas: frutíferas (pp. 141-246). Viçosa, MG: Imprensa Universitária.

Macarisin, D., Cohen, L., Eick, A., Rafael, G., Belausov, E., Wisniewski, M., \& Droby, S. (2007). Penicillium digitatum suppresses production of hydrogen peroxide in host tissue during infection of citrus fruit. Phytopathology, 97(11), 1491-1500. doi: 10.1094/PHYTO-97-11-1491

Menegon, A. P., Forcelini, C. A., \& Fernandes, J. M. C. (2005). Expansão de lesão por manchas foliares em cevada e sua interação com a aplicação foliar de fungicidas. Fitopatologia Brasileira, 30(2), 134-138. doi: 10.1590/S0100-41582005 000200005

Moosa, A., Sahi, S. T., Khan, S. A., \& Malik, A. U. (2019). Salicylic acid and jasmonic acid can suppress green and blue moulds of citrus fruit and induce the activity of polyphenol oxidase and peroxidase. Folia Horticulturae, 31(1), 195-204. doi: 10.2478/fhort-2019-0014

Morton, J. (1987). Tangor. In J. F. Morton, Fruits of warm climate (pp. 145-146). Miami: Echo Point Books \& Media.

Rocha, A. C. R. Neto, Maraschi, M., \& Di Piero, R. M. (2015). Antifungal activity of salicylic acid against Penicillium expansum and its possible mechanisms of action. International Journal of Food Microbiology, 215(2015), 64-70. doi: 10. 1016/j.jjfoodmicro.2015.08.018 
Palou, L. (2014). Penicillium digitatum, Penicillium italicum. In S. Banos-Bautista (Ed.), Postharvest decay, control strategies (pp. 45-102). Cambridge: Academic Press.

Perez, M. F., Ibarreche, J. P., Isas, A. S., Sepulveda, M., Ramallo, J., \& Dib, J. R. (2017). Antagonistic yeasts for the biological controlo f Penicillium digitatum on lemons stored under export conditions. Biological Control, 115, 135-140. doi: 10. 1016/j.biocontrol.2017.10.006

Qing-Yan, G., Jiao, J., Meng, L., Wei, W., Cheng-Bo, G., Yu-Jie, F., \& Wei, M. (2016). Tremendous enhancements of isoflavonoid biosynthesis, associated gene expression and antioxidant capacity in Astragalus membranaceus hairy root cultures elicited by methyl jasmonate. Process Biochemistry, 51(5), 642-649. doi: 10.1016/j.procbio.2016.01.012

Quaglia, M., Ederli, L., Pasqualini, S., \& Zazzerini, A. (2011). Biological control agents and chemical inducers of resistance for postharvest control of Penicillium expansum Link. on apple fruit. Postharvest Biology and Technology, 59(3), 307-315. doi: 10.1016/j.postharvbio.2010.09.007

Reis, M. A., Arf, O., Silva, M. G., Sá, M. E., \& Buzetti, S. (2008). Aplicação de silício em arroz de terras altas irrigado por aspersão. Acta Scientiarum Agronomy, 30(1), 37-43. doi: 10.4025/actasciagron.v30 i1.1126

Rodrigues, F. A., Resende, R. S., Dallagnol, L. J., \& Datnoff, L. (2015). Silicon potentiates host defense mechanisms against infection by plant pathogens. In F. Rodrigues, \& L. Datnoff (Eds.), Silicon and plant diseases (pp. 109-138). Basel, Switzerland: Springer Nature
Sánchez-Torres, P., \& Tuset, J. J. (2011). Molecular insights into fungicide resistance in sensitive and resistant Penicillium digitatum strains infecting citrus. Postharvest Biology and Technology, 59(2), 159-165. doi:10.1016/j. postharvbio.2010.08.017

Shaner, G., \& Finney, R. E. (1977). Effect of nitrogen fertilization on expression of slow-mildewing resistance in knox wheat. Phytopathology, 67, 1051-1056. doi: 10. 1094/Phyto-67-1051

Toju, H., Tanabe, A. S., Yamamoto, S., \& Sato, H. (2012). High-Coverage ITS primers for the DNA-based identification of ascomycetes and basidiomycetes in environmental samples. Plos One, 7(7), e40863. doi: 10.1371/journal.pone.0040863

Vallad, G. E., \& Goodman, R. M. (2004). Systemic acquired resistance and induced systemic resistance in conventional agriculture. Crop Science, 44(6), 1920-1934. doi: 10.2135/cropsci2004.1920

Zhichao, W., Fuhua, W., Shuai, L., Yingqiong, D., Furong, L., Ruiying, D., Jie, Z. (2016). Comparative responses to silicon and selenium in relation to cadmium uptake, compartmentation in roots, and xylem transport in flowering Chinese cabbage (Brassica campestris) L. ssp. Chinensisvar. utilis) under cadmium stress. Environmental and Experimental Botany, 131, 173-180. doi: 10.1016/j. envexpbot. 2016.07.012

Zhu, Z., Chen, Y., Shi, G., \& Zhang, X. (2017). Selenium delays tomato fruit ripening by inhibiting ethylene biosynthesis and enhancing the antioxidant defense system. Food Chemistry, 219, 179-184. doi: 10. 1016/j.foodchem.2016.09.138 
